\title{
7 The use of the archives of the Tuol Sleng Genocide Museum and the Documentation Centre of Cambodia by the Extraordinary Chambers in the Courts of Cambodia
}

\author{
Vincent de Wilde d'Estmael
}

\section{Historical, political, social and cultural contexts}

The Extraordinary Chambers in the Courts of Cambodia ("ECCC") began their work in the summer of 2006 with the conduct of preliminary investigations by the Co-Prosecutors and the holding of discussions between the national and international judges for the adoption of the Internal Rules. ${ }^{1}$ This was the culmination of lengthy negotiations between the Royal Government of Cambodia and the United Nations that were initiated by Cambodia in 1997, one year before the last Khmer Rouge leaders, occupying the border region with Thailand for 20 years, renounced the civil war and left Anlong Veng to surrender to the authorities in Phnom Penh. In the absence of credible trials ${ }^{2}$ and a willingness to try the Khmer Rouge leaders and perpetrators during the two decades following the fall of the Pol Pot and Nuon Chea regime, trials before the ECCC are the only judicial response to the abominable mass crimes (crimes against humanity, genocide and war crimes) committed during the 3 years, 8 months and 20 days that the regime of Democratic Kampuchea ("DK") lasted, between the capture of Phnom Penh on 17 April 1975 and the arrival of Vietnamese forces in the capital on 7 January 1979. Although very late, these trials are no less essential for the Cambodian people, for Asia and for the international community as a whole: they contribute to the fight against impunity against the senior leaders and those most responsible for the crimes committed; they establish the judicial truth, which is so important for the surviving victims and their families, but also for the memory of the 1.7-2.2 million dead; they also enable the active participation in the trials of the victims who were admitted as civil parties and who may benefit from symbolic and collective reparations in the absence of any individual financial compensation; finally, they contribute to the prevention of this type of dictatorial regime and the international crimes associated with it, by educating and raising 
the awareness of the population on the occasion of these trials. The substantive resources at the ECCC's disposal, the simultaneous access to all relevant evidence and the systematic analysis of this evidence also allow it to go beyond the work of the historians, researchers and other writers who have studied this era: judicial truth is more demanding than historical truth, because criminal facts must be established beyond reasonable doubt. The trials also aroused great interest among the Cambodian population, including young people whose parents and grandparents had too rarely talked about the hell they went through during that period, preferring to focus on the future by trying to dissimulate or forget the past and the depth of its traumas.

The discovery of Khmer Rouge archives in Phnom Penh and elsewhere in the country after 6 January 1979 has largely contributed to not burying past history and to establishing the facts. Thus, on 16 November 2018, the Trial Chamber pronounced its most important judgment since the establishment of the ECCC and sentenced the accused Nuon Chea and Khieu Samphan to life imprisonment in Case 002/02. ${ }^{3}$ They had already been sentenced to the same sentence in a first Trial 002/01. This second judgment in Case 002 concerned several security centres (prisons) and associated execution sites as well as work sites where the population was enslaved (work in communist "cooperatives," construction of dams and irrigation systems by hand and construction of a secret military airport). The Trial Chamber convicted the defendants for various crimes against humanity, including extermination, murder, enslavement, imprisonment, torture and persecution, as well as for the other inhumane acts of enforced disappearance, forced marriages and rape in the context of forced marriages, and various war crimes (in the context of the armed conflict with Vietnam). The judgment also recognised the existence of two separate genocides during this period in Cambodia: one perpetrated against the Cham minority and the other against the Vietnamese. This criminal case is probably the largest and most complex in the history of international criminal law since Nuremberg.

The Case 002/02 Judgment as well as the two appeal judgments issued previously (including the Case 001 appeal judgment against Kaing Guek Eav alias Duch, the director of the notorious S-21 security and torture centre) constitutes the culmination of a very long process of preliminary inquiries, investigations and lengthy trials. These proceedings were distinguished both by the volume of information to be processed, by the number of deaths resulting from the crimes committed (estimated at between 1.7 million and 2.2 million people) and the nature, gravity and duration of the international crimes committed. What makes these trials peculiar and even more complex compared to others (ICTR, ICTY, SCSL, etc.) is, among other things, the passage of time. While the ECCC began its activities 31 years after the capture of Phnom Penh by the Khmer Rouge communist revolutionary forces 
on 17 April 1975, the judgment in Case 002/02 was issued almost 40 years after the DK regime was toppled in January 1979.

\section{Usefulness of the Democratic Kampuchea archives versus oral testimony}

One knows how fallible human memory can be, especially after several decades. The older the witnesses, civil parties and accused get, the harder it is for them to reconstruct past events in all their details, and in particular to situate them in time or in chronological order: the description of a significant or traumatic event is often constant, but some witnesses and civil parties may confuse months or years all the more easily because under the Khmer Rouge regime they had neither watches, calendars nor radios and thus no precise time markers. It was therefore essential for prosecutors, investigating judges and their investigators, trial judges and parties to trials to be able to question witnesses, civil parties and experts on the basis of objective facts and precise dates as they appeared in DKera documents. Thus, the co-prosecutors relied heavily on these contemporary documents to lend credibility to the statements of witnesses or civil parties whenever they corroborated objectively proven facts. With the witnesses who were reluctant to cooperate with the judicial system because they themselves, as Khmer Rouge cadres or perpetrators, had taken an active part in the implementation of the Communist Party policies and the crimes that resulted from them, it was equally important to be able to confront them with the DK documents that detailed these policies or crimes committed.

Without the documents of the Khmer Rouge regime, only a small part of which could be found and preserved, the ECCC trials might not have seen the light of day. Without them, it would have been indeed much more difficult to prosecute the Khmer Rouge senior leaders and those most responsible for the crimes committed. These contemporaneous archives have in fact made it possible to clarify the roles and functions of the DK leaders and the various civilian and military institutions at the head of the country (and, therefore, the decision-making and chain of command), whereas there was little direct testimonial evidence on this subject. They also provided an understanding of the internal functioning of the Communist Party of Kampuchea ("CPK"), the major policies and guiding principles formulated and implemented by the country's leaders, as well as the communication between the Phnom Penh-based leaders and other senior officials stationed in the various civilian zones and military divisions of the country. Despite the destruction of most of them, the DK-era archives that were retrieved were so numerous (hundreds of thousands of pages) that when it came to determining which suspects, crime sites and types of crimes to prosecute in their introductory submissions, the analysis of these DK documents was initially given priority over the conduct of investigative missions in the field. 


\section{Nature of the archives of Democratic Kampuchea found and methods of conservation}

Among the archive lots that were not destroyed by the Khmer Rouge cadres before they fled or by simple ignorance by the population after 6 January 1979 are the following: (1) numerous documents from the S-21 security centre that were recovered at the Tuol Sleng school - the prison itself - and in the many surrounding houses that were used as places of interrogation and torture ${ }^{4}$; they are kept in original or copy form at the Tuol Sleng Genocide Museum, along with some documents from Kraing Ta Chan prison that were deposited there; (2) a batch of documents dating from 1975 and 1976 which was found in the early 1980s in a house in Phnom Penh clearly occupied by a member of the Standing Committee of the CPK Central Committee, probably that of Son Sen, the former Minister of Defence; (3) various documents collected in 1979 and in the 1980s which have been kept by the National Archives of Cambodia; (4) audiovisual archives collected and preserved at the Bophana Centre in Phnom Penh. These separate batches of DK archives, as well as other batches discovered or later returned to Cambodia, notably by researchers, journalists or former foreign communist sympathizers, were for the most part collected, categorised, digitised and preserved in their original form by the organisation Documentation Centre of Cambodia ("DC-Cam"), whose mission is to collect documents relating to this period and make them accessible to the public, either on-site or via their website. While some foreign States and individuals have returned or communicated their relevant archives to Cambodia, to DC-Cam and/or directly to the ECCC (France, the United States, Sweden), others, such as China or Vietnam, have remained deaf to the repeated requests from the DC-Cam and the ECCC to access their documentation concerning their relations at the time with the regime of Pol Pot and Nuon Chea.

Without the fruitful collaboration of the Documentation Centre of Cambodia, the Genocide Museum, the Bophana Centre and the National Archives with the ECCC from the beginning of their work, be it with the office of the co-prosecutors first but also with the office of the co-investigating judges, the various defence teams, the civil parties and the Chambers, it would have been difficult to access these numerous archives and collections of documents, then to select and analyse them. Thanks in particular to the work carried out by the DC-Cam to preserve, classify and more recently digitise these archives, it has been possible for the different ECCC actors to easily access and use them as required by the judicial process. This demonstrates the crucial role played by this type of civil society organisation firstly for the collective memory and the establishment of historical facts and, subsequently, for the judicial proceedings, especially during the long period when the priority was not to prosecute and try the main leaders and those responsible for these crimes. It is so crucial for the administration of justice to collect as much evidence as possible at the time of the crimes or just 


\section{Vincent de Wilde d'Estmael}

after they were committed that the Cambodian example has provided some lessons and has inspired, inter alia, the recent establishment by the United Nations of two impartial and independent mechanisms to collect, preserve and analyse evidence of the crimes committed in Syria and Myanmar.

The types of archives from the DK era that were used in the trials at the ECCC are varied. An analysis of the evidence used in Trial 002/02 demonstrates this. Of the 10,500 pieces of documentary evidence admitted by the Trial Chamber during the proceedings, nearly 4,000 pieces originated from the Communist Party itself during the DK regime, not counting other contemporary documents from foreign countries (including press articles, telegrams, reports and minutes of meetings about the situation in Cambodia).

Of these 4,000 documents, more than half $(2,148)$ originated from or concerned the security centres of S-21 in Phnom Penh (2,011 documents, 94\%) and of Kraing Ta Chan in Tram Kak District (137 documents, 6\%). The S-21 documents used in Trial 002/02 miraculously survived instructions from Communist Party leaders to destroy all archives before fleeing from the Vietnamese. It is questionable to this day why Duch, the director of S-21, did not see to the destruction of these highly secret documents in his security centre. Although he has stated that he did not receive direct instructions from Nuon Chea to destroy these documents before he fled, several other factors may help to answer this question: among them are negligence; the scattering of these archives; the lack of time to carry out this systematic destruction at the beginning of January 1979, at a moment when Duch urgently had to execute hundreds of prisoners on Nuon Chea's orders; Duch's conscious or unconscious willingness to leave behind evidence that he had carried out his duties in a professional and zealous manner, or even to document the crimes committed by the regime; or the surprise at the speed with which the Vietnamese arrived to capture Phnom Penh. Duch explained that Nuon Chea later severely criticised him for not destroying the archives. And for good reason: the ECCC legal proceedings were based on those archives, among other things. Moreover, these archives establish that Nuon Chea was Duch's immediate supervisor in relation to S-21 from mid-1977 onwards and the fact that numerous confessions extracted at S-21 were communicated to him.

S-21 records used as documentary evidence in Trial 002/02 include 89 summary biographies of prisoners prepared upon entry into S-21; 1,139 lists and logs of prisoners (including the name, age and former positions of prisoners, as well as their place of arrest and date of entry into S- 21); 154 daily lists of persons interrogated (mentioning the name of the interrogator and the method of interrogation used); 465 confessions extracted from prisoners, which relate to their betrayal of the Party or their status as enemies (these confessions include annotations by Son Sen and/or Nuon Chea in addition to those by Duch, as well as long lists of "accomplices" whom the prisoners were forced to denounce and who could in turn be arrested); 49 lists 
of people who were executed or who died in their cells (some with several hundred names); 118 reports and notebooks prepared by S-21 staff members; as well as dozens of photographs of prisoners (not included in the 2,011 document total), sometimes with their names on the back of the photos. In some cases, it is possible to follow a prisoner's steps in S-21 from the entry to interrogation under torture and execution whenever his/her name appears on various types of documents. The archives found at S-21 were often authenticated during the three trials conducted so far by Duch, interrogators, the registrar, photographers or guards who worked at S-21. The combination of the data contained in these S-21 documents enabled the co-investigating judges' office to determine that at least 15,101 persons had been imprisoned at S-21. Of these, only a handful of prisoners survived. The Office of the Co-Prosecutors continued this analysis by including more execution lists and photographs of named prisoners and concluded later that at least 18,133 persons were imprisoned at S-21.

This work is currently continuing after analysing additional S-21 documents that were not previously considered. However, the Trial Chamber in its Judgment 002/02 retained a very conservative number of at least 11,742 S-21 prisoners executed based only on certain categories of documents from S-21. ${ }^{6}$ Beyond the precise figures, the statistics relating to the entries and executions of prisoners in S-21 show that the years 1977 and 1978 were the most murderous years when purges among Party cadres were in full swing in many areas, regions and military divisions of the country.

Apart from the documents from S-21 and Kranig Ta Chan (two out of approximately 200 security centres in the country), the other contemporaneous archives used during Trial 002/02 have shed important light on the functioning of the regime. They included 71 minutes of meetings of the Standing Committee, the CPK Central Committee, the Military General Staff and the Council of Ministers. The more than 20 minutes of meetings held mainly in 1975 and 1976 between the DK top leaders within the Standing Committee are particularly important. They detail a number of policies, appointments and planned actions. These meetings were held weekly or more frequently in case of emergencies. Khieu Samphan himself acknowledged the authenticity of these minutes and the frequency of these meetings which he attended most often. These archives also included $100 \mathrm{CPK}$ publications, including official magazines and instructions for party members or party youth; 61 government statements, 245 activity reports of local cadres, both civilian and military; 212 telegrams exchanged between the ruling bodies and the zones and military divisions; 172 archives of the Ministry of Commerce; 271 media reports and 354 photographs and propaganda films of the regime. Among these contemporary documents, an important source of information, particularly for determining the activities of the DK leaders Kampuchea, are the transcripts of all radio broadcasts by the Khmer Rouge regime at the time, both by the CIA ("FBIS" reports)" and by the 
BBC ("BBC/SWB" reports). ${ }^{8}$ Speeches by Pol Pot, Nuon Chea, Ieng Sary or Khieu Samphan frequently appear in these transcripts. Some of these same speeches have been found in hard copy in the DK official documents as well, which makes it easy to authenticate them, given the existence of two distinct sources for speeches with identical content.

All these documents emanating from the regime have helped to establish the regime's murderous utopia, particularly through the existence of policies relating to the creation and operation of "cooperatives" (collective production units where any form of individual ownership was prohibited), to the forced movement of populations, the treatment of internal and external enemies, including targeted groups such as Buddhists, Cham, Vietnamese and former soldiers and officials of the previous Khmer Republic regime, and to the common practice of forced marriages.

\section{Reliability and authenticity of the archives of Democratic Kampuchea}

The content and truthfulness of documents issued by the regime itself can hardly be contested once they are authenticated or contain numerous internal or external indicia of reliability (such as general appearance, headings and emblems, language and style used, handwriting, signatures, consistency of content mentioning known events or the names of Khmer Rouge cadres or of proven victims). The contemporaneous documents proposed by the parties were generally found admissible by the Trial Chamber, and the allegations of forgery or lack of relevance and reliability made by the Defence were overwhelmingly rejected. Regarding the collection, preservation, archiving and chain of custody of the contemporaneous documents obtained by the ECCC from DC-Cam, its leaders Youk Chhang and Vanthan Dara were questioned at length by the judges and the parties in court. The Trial Chamber concluded that the methodology used was reliable and that the contemporaneous DK-era documents originating from DC-Cam were presumed to be prima facie relevant and reliable, including with regard to their authenticity, and that there was no reason to fear that the documents originating from this source could have been subject to tampering, distortion or falsification. ${ }^{9}$ The Supreme Court Chamber validated this finding on appeal. ${ }^{10}$ The Trial Chamber also found that all parties to the trials had had equal access to all the archives from DC-Cam. Once the documents were found admissible, the Chamber assessed their probative value on a case-by-case basis. It should be noted that a very large number of DK documents were authenticated during the hearings by former Khmer Rouge cadres, including Duch and other S-21 cadres, but also by senior CPK cadres, as well as by Khieu Samphan during the investigation phase. Finally, it was considered that many facts and names 
mentioned in these DK documents had been corroborated by numerous other independent sources, including other contemporaneous documents collected in other places. Only a few documents proposed by the parties were rejected by the Trial Chamber under the criteria set out in Internal Rule $87(3),{ }^{11}$ generally because they were deemed unreliable or irrelevant to the scope of the trial, or sometimes because they were illegible. ${ }^{12}$

With regard to the documents found at S-21, and in particular the "confessions" forcibly obtained from the prisoners, the Trial Chamber has clarified in its jurisprudence that extremely narrow limits have been imposed on the use of evidence containing information obtained under torture, pursuant to Article 15 of the United Nations Convention against Torture. Thus, it was held that confessions obtained under torture in S-21 could only be used as evidence against the persons accused of torture, and only to establish that the confessions had been made, and not to prove the truthfulness of their contents. However, the Trial Chamber deemed that limited objective information appearing in the documents containing the confessions (such as the identity of the prisoner and the date of his/her arrest or execution) was not part of the statements obtained under torture themselves and could be used. The same applies to the handwritten annotations by Duch, his interrogators, or by Son Sen and Nuon Chea in the margins of the confessions. These annotations indicated, inter alia, to whom the confessions were communicated and what type of torture had been applied in order to obtain the prisoner's full confession. ${ }^{13}$

\section{Conclusion}

The trials of the senior leaders and those most responsible for the crimes committed between April 1975 and January 1979 in Cases 001 and 002 were initiated and completed largely due to the discovery and proper preservation of documents from the Democratic Kampuchea era. These were considered by the Extraordinary Chambers to be among the most important and reliable sources of evidence. The additional insights provided in court by witnesses, civil parties and experts on the content of these documents and their in-depth analysis by the parties and the judges enabled the Chambers to establish the judicial truth about the charges brought against the accused and to offer certain forms of collective reparations. When the judicial proceedings have been completed at the ECCC, all the evidence documents that make up the ECCC's files, whether from the DK-era or after January 1979, will enable researchers, historians and jurists to draw from them the information they need to continue their work and thus further contribute to the preservation of memory. At present, it has not yet been determined which state organ(s) or which independent body(ies) will be the depositories of these archives. What matters is that, like the archives 
of the Tuol Sleng Genocide Museum and those collected and catalogued by the Documentation Centre of Cambodia, the ECCC's records should be kept and preserved by a credible, independent and neutral institution offering free and easy access to the Cambodian population and to foreigners interested in these subjects.

\section{Notes}

1 Adopted on 12 June 2007 and amended several times since then.

2 A symbolic trial in absentia was indeed organised in Phnom Penh by the Vietnamese authorities against the accused Saloth Sar alias Pol Pot and Ieng Sary alias Van (before the People's Revolutionary Court). It lasted only two days and a judgment was pronounced at its end on 19 August 1979. Although a great deal of evidence was presented and witnesses for the prosecution were indeed heard, the absence of the accused and the failure to respect defence rights removed all credibility from this hasty form of justice, devoid of impartiality and independence. There has been no other major attempt to try the perpetrators of the crimes committed under Democratic Kampuchea since then.

3 The two other accused in Case 002, namely Ieng Sary, Deputy Prime Minister and Minister of Foreign Affairs (and member of the Standing Committee of the Communist Party) and his wife Ieng Thirith, Minister of Social Affairs in charge of the entire health sector under the DK regime, could not be tried. Ieng Sary died of illness during the Trial 002/01, on 14 March 2013, while his wife had previously been declared unfit to stand trial due to dementia in November 2011. She subsequently died in August 2015.

4 The recovered documents do not constitute the totality of the documents established in S-21. Many of them were used in the months and years following the Khmer Rouge leaders' flight as wrapping paper for foodstuffs at the nearby Tuol Tumpoung market; others were used as fuel or were thrown away or buried out of ignorance by a population - often uneducated - whose sole concern was to ensure its survival after the fall of the regime.

5 The S-21 Security Centre is a crime site in case files 001, 002 and 003. The latter case concerns accused Meas Muth, commander of the Navy and of Division 164 within the Revolutionary Army of Kampuchea and secretary of the Kampong Som Autonomous Sector.

6 ECCC, E465 Case 002/02 Judgment, 16 November 2018, para. 2542.

7 Foreign Broadcast Information Service.

8 Summary of World Broadcasts (by the BBC).

9 ECCC, Case 002 E185 Decision on Objections to documents proposed to be put before the Chamber on the Co-Prosecutors' Annexes A1-A5 and to documents cited in paragraphs of the Closing Order relevant to the first two trial segments of Case 002/01, 9 April 2012, para. 28. The principles established in this decision were confirmed in Judgments E313 (Case 002/01), 7 August 2014, para. 34 and E465 (Case 002/02), 16 November 2018, para. 46.

10 ECCC F36, Appeal Judgment, Supreme Court Chamber (Case 002/01), 23 November 2016, paras 373-375.

11 ECCC Internal Rule 87 (3) provides that "The Chamber may reject a request for evidence when it finds that it is: (a) irrelevant or repetitious; (b) impossible to obtain within a reasonable time; (c) unsuitable to prove the facts it purports to prove; (d) not allowed under the law; or (e) intended to prolong proceedings or is frivolous." 
12 Thus, in the same Framework Decision on E185 of 9 April 2012 (Case 002/01), the Trial Chamber refused the admissibility of 10 documents (out of more than 1,400 documents) because 9 of them were deemed irrelevant and unreliable and 1 was illegible; ECCC, E185/1 (Case 002/01), 3 December 2012, Decision on objections to documents proposed to be put before the Chamber in Co-Prosecutors' Annexes A6-A11 and A14-A20 and by the other parties [7 documents were found inadmissible for irrelevance out of a total of 3,595 documents, a majority of which originated from Democratic Kampuchea].

13 See, for example, ECCC, E465, Case 002/02 Judgment, 16 November 2018, para 74-77. 